\title{
Preliminary ecology research on Epipactis atrorubens (Hoffm.) Besser on the Słowińskie Coast (Northern Poland)
}

\author{
"Agnieszka Parzych, **Zbigniew Sobisz \\ *Environmental Chemistry Research Unit \\ ${ }^{* *}$ Botany and Genetics Research Unit, Institute of Biology and Environmental Protection, \\ Pomeranian Academy, 22 Arciszewskiego St., 76-200 Słupsk, Poland, \\ e-mail: parzycha1@op.pl
}

\begin{abstract}
The research covered three stands of Epipactis atrorubens on the Słowińskie Coast (Rowy, Wicko Morskie and Jarosławiec). The plants in blossom were characterized on the basis of seven individual characteristics: height, the number of leaves, the number of flowers per inflorescence, the length and width of the largest leaf and stipule. Statistically significant differences were found in the studied populations between the height of the plant and the width of the largest leaf, the number of flowers per inflorescence and the inflorescence length up to the bract, as well as between the number of flowers per inflorescence and the inflorescence length up to the bract. The populations of E. atrorubens on the Słowińskie Coast cover the mineral soil with the dominance of medium- and fine sand fractions. Those soils are loose with very low water capacity and good permeability. The organic matter content varied from 0.4 to $0.8 \%$. The soil reaction is low acid or close to alkaline. The analyzed soil samples were characterized by very low content of exchangeable $\mathrm{Al}^{3+}$ ions, which results from relatively high $\mathrm{pH}$ levels. The soil salinity was low and the average content of $\mathrm{NaCl}$ was between 0.146 and $0.181 \mathrm{~g} \cdot \mathrm{dm}^{-3}$.
\end{abstract}

Key words: Orchidaceae, Epipactis atrorubens, morfological characteristics, biometry, coastal grey dunes, Helichryso-Jasionetum litoralis, soil properties.

\section{Introduction}

Orchidaceae constitute one of the largest families of angiospermous plants comprising about 25000 species (Szweykowska \& Szweykowski 2006; Tsiftsis et al. 2008). The Epipactis genus is represented globally by 30 species, of which about 25 are found in Europe (Brzosko et al. 2006). In Poland, depending on the source of information, there are five (Brzosko et al. 2006) or even eight species of that genus according to Szlachetko (2001). Epipactis atrorubens is a species found in Europe and Asia. In Europe, the distribution of the plant is wide. It spreads from the British Isles and Scandinavia to Spain, Italy, Greece, the Balkan Peninsula and as far as Crimea (Vakhrameeva et al. 2008). In Asia, E. atrorubens is found in Asia Minor - in the Northern Iran, the Caucasus, in Central Asia and in
Eastern Siberia. The species grows in Bielorussia, Estonia, Georgia, Kazachstan, Lithuania, Latvia and Moldova as well as in Russia and Ukraine (Tuulik 1998; Vakhrameeva et al. 2008). In Poland, E. atrorubens stands are found both in the North and in the South (Brzosko et al. 2006; Szlachetko 2001). The ecology of E. atrorubens has not been sufficiently recognized, and information in this scope is very general (Jurkiewicz et al. 2001; Brzosko et al. 2006; Kull \& Hutchings 2006; Tsiftsis et al. 2008; Tałataj \& Brzosko 2008; Vakhrameeva et al. 2008; Jakubska-Busse 2009). Recognition of ecological conditions of E. atrorubens is indispensable to safeguard its effective protection.

The aim of the study was consisted of search for relationship between morphological features, comparison of biometric features of three populations and characterization of soils on their habitats. 


\section{Material and methods}

\subsection{Study area}

The research comprised three stands of E. atrorubens at the Słowińskie Coast (Fig. 1). The first stand (the area of $800 \mathrm{~m}^{2}$ ) was situated in Rowy, at a grey dune on the right bank of the Łupawa outlet to the Baltic Sea. The second stand (the area of $700 \mathrm{~m}^{2}$ ) was situated in Wicko Morskie at a grey dune situated at the marine military training area, along the road between the division of: $98 \mathrm{~b} / 101 \mathrm{~b}$ the Modlinek Forest Distict and 102b the Zalaski Forest District (Ustka Forest Inspectorate). The third research area (the area of $550 \mathrm{~m}^{2}$ ) was situated in Jarosławiec at the sandy plateau of a cliff crown (the entrance to the beach from the side of Aqua Park).

\subsection{Field and laboratory work}

The research was done at the turn of June and July 2010, during which the phytosociological records (relevés) were taken by application of the method of Braun Blanquet (1964). Nomenclature of the vascular plant species was adopted after Mirek et al. (2002), while the nomenclature of the moss after Ochyra et al. (2003). The research area was divided into squares of $1 \mathrm{~m}$ side each. The numerical force and density (the number of plants per $1 \mathrm{~m}^{2}$ ) of the popula- tion was specified by calculating specimens from particular squares of each research standing. The age structure of the population was determined assuming after Łukasiewicz (1962) and Sarosiek et. al. (1990) four development phases of E. atrorubens: 1 - juvenile (i.e. one-two leaves), 2 - immature (growing, i.e. three-four leaves), 3 - virginal (vegetatively development, non-flowering, more than 5 leaves) and 4 - generative (flowering).

The plants in blossom were characterized on a basis of seven individual features: height, number of leaves, number of flowers in inflorescence, the length and width of the largest leaf and stipule. The measurement of the height, length and width was done with accuracy up to $1 \mathrm{~mm}$. In order to specify edaphic conditions, the soil samples from the rhizosphere of the examined plants were taken. The mechanical composition of the soil was specified by means of application of the dry mesh method, active acidity $\left(\mathrm{pH}_{\mathrm{H} 2 \mathrm{O}}\right)$ and exchangeable acidity $\left(\mathrm{pH}_{\mathrm{KCl}}\right)$ by means of the potentiometric, exchangeable aluminum by means of the Sokolov method, salinity - by the conductometric method, and organic matter in a muffle furnace at the temperature of $550^{\circ} \mathrm{C}$ (Karczewska \& Kabała 2008).

\subsection{Statistical analysis}

The obtained results of the research tests were verified by statistical methods (Wołek 2006), with application of Statis-

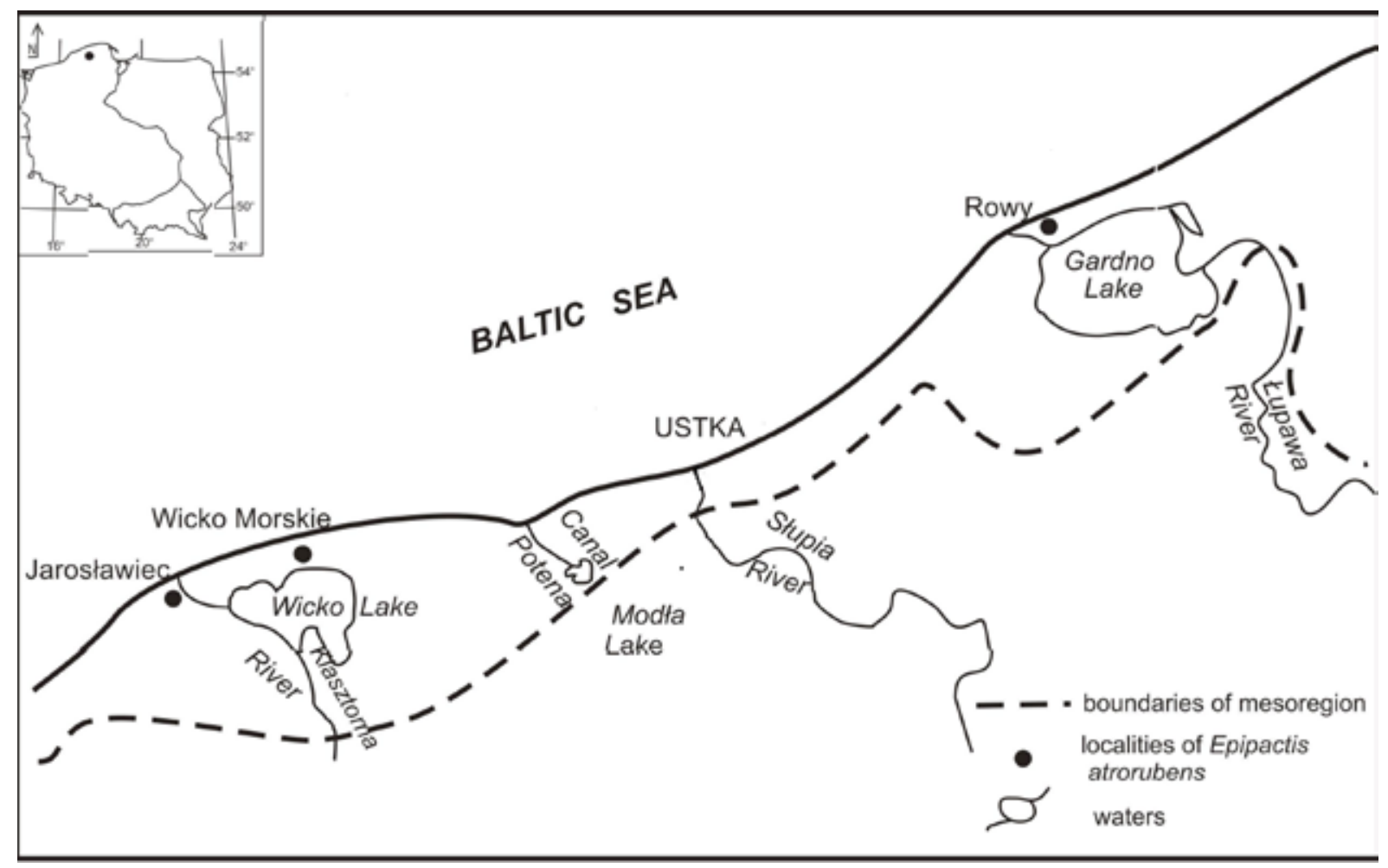

Figure 1. Situation plan of the Słowińskie Coast - locations of the study site 
tica software (7.1). The statistical distribution of the height of the tested plants at a generative stadium is represented by bar charts. Normality of distribution of the studied was tested using the Shapiro-Wilk test. In order to compare validity of differences of individual features of examined plants among three designated stands, the parameter Anova (analysis of variance) test was applied. In order to compare and characterize the chemical composition of the soil, mean values, standard deviations, coefficients of variation (\%) and the Pearson's correlation coefficients were calculated.

\section{Results and discussion}

\subsection{Biotic conditions}

The examined population of Epipactis atrorubens is a component of phytocoenoses with Helichrysum arenari$u m$ and Jasione montana, which belong to the association
Helichryso-Jasionetum litoralis Libb. 1940 (Table 1), and form compact patches of turf on dune sands of marine accumulation. Such patches of turf are characteristic of grey dunes with fixed sand free of salt (Matuszkiewicz 2008). Two subassociations can be distinguished within this association: a typical one and with the cup-lichen (Cladonia). The cup-lichen subassociation is characterised by exuberant development of the lichen and moss layer with a minor contribution of herbaceous species. It develops mostly in inland areas, usually close to forest (Braun 2010). The species characteristic of Helichryso-Jasionetum litoralis Libb. 1940 are Jasione montana var. litoralis, Artemisia campestris subsp. sericea and Hieracium umbellatum var. dunense. The distinguished species comprise Epipactis atrorubens, Eryngium maritimum and Linaria odora. There are numerous species of Koelerio glaucae-Corynephoretea canescentis and Molinio-Arrhenatheretea. The Molinio-Arrhenatheretea class is more frequently represented by: Festuca rubra, Achillea millefolium and Poa annua.

Table 1. Social structure of community Helichryso-Jasionetum litoralis Libb. 1940

\begin{tabular}{|c|c|c|c|c|c|c|c|}
\hline Succesive number & 1 & 2 & 3 & 4 & 5 & \multirow[b]{14}{*}{ Lw } & \multirow[b]{14}{*}{$\mathrm{D}$} \\
\hline Number of phytosociological relevé & 21 & $21 \mathrm{a}$ & 27 & 24 & $24 \mathrm{a}$ & & \\
\hline Date (day, month, year) & 21.06 & 12.07 . & 28.06 & 24.06 & 12.07 & & \\
\hline & 2010 & 2010 & 2010 & 2010 & 2010 & & \\
\hline Locality & $\mathrm{R}$ & $\mathrm{R}$ & $\mathrm{W}$ & $\mathrm{J}$ & $\mathrm{J}$ & & \\
\hline Stand & $\begin{array}{l}\text { grey } \\
\text { dune }\end{array}$ & $\begin{array}{l}\text { grey } \\
\text { dune }\end{array}$ & $\begin{array}{l}\text { grey } \\
\text { dune }\end{array}$ & cliff & cliff & & \\
\hline Exposition & & & & & $\mathrm{SE}$ & & \\
\hline Inclination $\left[{ }^{\circ}\right]$ & & & & & 5 & & \\
\hline Area of relevé $\left[\mathrm{m}^{2}\right]$ & 50 & 40 & 50 & 50 & 60 & & \\
\hline \multirow[t]{2}{*}{ Crown density [\%] } & 15 & 5 & 5 & 5 & 5 & & \\
\hline & 20 & 10 & 45 & 30 & 25 & & \\
\hline \multirow[t]{2}{*}{ Cover of plant layers [\%] } & 45 & 55 & 70 & 80 & 60 & & \\
\hline & 15 & 5 & 15 & 5 & 5 & & \\
\hline Number of species in phytosociological relevé & 33 & 29 & 32 & 24 & 37 & & \\
\hline \multicolumn{8}{|l|}{ I. ChAss. Helichryso-Jasionetum litoralis } \\
\hline Artemisia campestris subsp. sericea & + & . & + & 1.1 & . & 3 & 140 \\
\hline Jasione montana var. litoralis & • & + & + & . & 1.1 & 3 & 140 \\
\hline Hieracium umbellatum var. dunense & + & . & + & . & + & 3 & 60 \\
\hline \multicolumn{8}{|l|}{ II. DAss. Helichryso-Jasionetum litoralis } \\
\hline Epipactis atrorubens & 3.3 & 2.2 & 3.3 & 2.2 & 1.2 & 5 & 2300 \\
\hline Linaria odora & 1.1 & 1.1 & . & . & . & 2 & 200 \\
\hline Eryngium maritimum & . & 2.2 & . & . & . & 1 & 350 \\
\hline
\end{tabular}


*Carex arenaria

Anthyllis vulneraria subsp. maritima

Sedum acre

Trifolium arvense

Corynephorus canescens

Rumex acetosella

*Ammophila arenaria

**Petasites spurius

Helichrysum arenarium

Festuca ovina

**Peucedanum oreoselinum

Brachythecium albicans

Ceratodon purpureus

**Astragalus arenarius

IV. ChCl. Festuco-Brometea

Euphorbia cyparissias

Centaurea stoebe

V. ChCl. Artemisietea, ChO. Onopordetalia acanthi*

*Nepeta cataria

Artemisia vulgaris

* Echium vulgare

\section{ChCl. Vaccinio-Piceetea}

Melampyrum pratense

Leucobryum glaucum

Hylocomium splendens

\begin{tabular}{|c|c|c|c|c|c|c|}
\hline 1.1 & 1.2 & 2.2 & 1.2 & 1.1 & 5 & 750 \\
\hline+ & + & $\cdot$ & 3.3 & 1.1 & 4 & 890 \\
\hline+ & . & 1.2 & 1.1 & +.2 & 4 & 240 \\
\hline+ & + & + & $\cdot$ & 1.1 & 4 & 160 \\
\hline+ & . & + & + & + & 4 & 80 \\
\hline+ & +.2 & + & + & . & 4 & 80 \\
\hline$\cdot$ & 1.2 & + & . & 1.2 & 3 & 220 \\
\hline+ & +.2 & . & + & . & 3 & 60 \\
\hline - & + & 1.2 & . & $\cdot$ & 2 & 120 \\
\hline - & $\cdot$ & - & + & 1.2 & 2 & 120 \\
\hline • & • & - & + & 1.1 & 2 & 120 \\
\hline - & 1.2 & - & . & $\cdot$ & 1 & 100 \\
\hline . & . & . & . & 1.2 & 1 & 100 \\
\hline+ & . & - & . & . & 1 & 20 \\
\hline
\end{tabular}

Pyrola minor

Vaccinium vitis-idaea

\section{ChCl. Stellarietea mediae}

Vicia hirsuta

Conyza canadensis

Hordeum murinum

Bromus sterilis

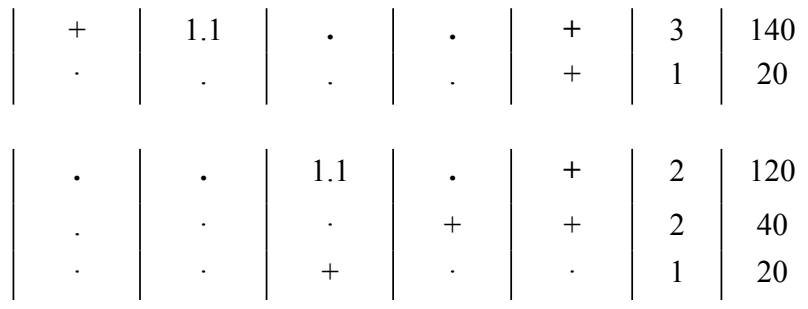

VIII. ChCl. Molinio-Arrhenatheretea, ChO. Plantaginetalia majoris*, ChAll. Arrhenatherion elatioris**

Festuca rubra

Achillea millefolium

*Poa anna

*Lolium perenne

Trifolium pratense

Plantago lanceolata

**Galium mollugo

Trifolium repens

Lotus corniculatus

Cerastium holosteoides

IX. ChCl. Nardo-Callunetea. ChO. Calluno-Ulicetalia*

*Calluna vulgaris

Hieracium pilosella

*Sarothamnus scoparius

\begin{tabular}{c|c|c|c|c|c|c|c} 
& + & + & + & $\cdot$ & + & 4 & 80 \\
$\mathrm{~d}$ & 2.2 & + & $\cdot$ & $\cdot$ & $\cdot$ & 2 & 370 \\
$\mathrm{~d}$ & $\cdot$ & $\cdot$ & + & 1.2 & $\cdot$ & 2 & 120 \\
& + & + & $\cdot$ & $\cdot$ & $\cdot$ & 2 & 40 \\
& $\cdot$ & $\cdot$ & + & $\cdot$ & + & 2 & 40
\end{tabular}

ChAll. Salicion arenariae

\begin{tabular}{|c|c|c|c|c|c|c}
+ & + & 1.2 & 1.1 & 1.2 & 5 & 340 \\
+ & + & + & + & + & 5 & 100 \\
+ & + & + & + & + & 5 & 100 \\
+ & + & $\cdot$ & $\cdot$ & + & 3 & 60 \\
+ & + &. &. & + & 3 & 60 \\
+ & $\cdot$ & + & $\cdot$ & + & 3 & 60 \\
. &. & + & + & + & 3 & 60 \\
+ & $\cdot$ &. &. & + & 2 & 40 \\
. & $\cdot$ & + & $\cdot$ & $\cdot$ & 1 & 20 \\
. & $\cdot$ & $\cdot$ & + & $\cdot$ & 1 & 20
\end{tabular}

\begin{tabular}{c|c|c|c|c|c|c}
$\cdot$ & $\cdot$ & 3.3 & $\cdot$ & +.2 & 2 & 770 \\
$\cdot$ & $\cdot$ & 1.2 & $\cdot$ & 1.2 & 2 & 200 \\
$\cdot$ & $\cdot$ & + & $\cdot$ & $\cdot$ & 1 & 20
\end{tabular}




\begin{tabular}{|c|c|c|c|c|c|c|c|c|}
\hline Salix arenaria & $\mathrm{b}$ & 2.2 & 1.1 & 1.2 & - & . & 3 & 550 \\
\hline Hippophaë rhamnoides subsp. maritima & $\mathrm{b}$ & • & . & . & - & 2.2 & 1 & 350 \\
\hline \multicolumn{9}{|l|}{ XI. Accompanying species } \\
\hline Pinus sylvestris & $\mathrm{a}$ & 2.2 & 1.2 & 1.1 & 1.1 & 1.1 & 5 & 750 \\
\hline Rosa rugosa & $\mathrm{b}$ & + & 1.1 & . & 2.2 & 1.2 & 4 & 570 \\
\hline Polypodium vulgare & & + & 1.1 & . & 1.2 & 1.2 & 4 & 320 \\
\hline Pinus sylvestris & $\mathrm{b}$ & $\cdot$ & . & 1.2 & 2.2 & +.2 & 3 & 470 \\
\hline Pinus mugo & $\mathrm{b}$ & 1.2 & +.2 & . & $\cdot$ & 1.1 & 3 & 220 \\
\hline Betula pendula & $\mathrm{b}$ & . & + & + & $\cdot$ & + & 3 & 60 \\
\hline Salix acutifolia & $\mathrm{b}$ & + & +.2 & . & . & . & 2 & 40 \\
\hline Medicago lupulina & & + & · & · & + & . & 2 & 40 \\
\hline Cladonia sylvatica & $\mathrm{d}$ & . & - & 2.2 & . & - & 1 & 350 \\
\hline Equisteum hyemale & & + & . & - & $\cdot$ & . & 1 & 20 \\
\hline Veronica chamaedrys & & $\cdot$ & . & . & + & . & 1 & 20 \\
\hline Galeopsis tetrahit & & $\cdot$ & . & . & . & + & 1 & 20 \\
\hline
\end{tabular}

R - Rowy; W - Wicko; J - Jarosławiec; Lw - number of appearance; D - cover coefficient; SE - exhibition south-east

In the herbaceous layer of the complexes the dominating species are Epipactis atrorubens, Anthyllis vulneraria subsp. maritima, Carex arenaria and Calluna vulgaris. The coverage coefficient (D) for these plant is 2300 (E. atrorubens), 890 (Anthyllis vulneraria subsp. maritima), 750 (Carex arenaria) and 770 (Calluna vulgaris) respectively. In the moss layer, there are Brachythecium albicans, Ceratodon purpureus, Cladonia sylvatica, Hylocomium splendens) and Leucobryum glaucum. In the tree layer, there is only one species, Pinus sylvestris. The shrubs layer is represented by Betula pendula, Hippophaë rhamnoides subsp. maritima, Pinus mugo, Pinus sylvestris, Rosa rugosa and Salix acutifolia.

\subsection{Individual features}

The examined populations of Epipactis atrorubens contained from 307 to 393 individuals, each one being at different stage of development. The plants in blossom constituted from $31 \%$ in Jarosławiec to $64 \%$ in Wicko Morskie (Table 2). Comparison of the frequency of development stages shows that the plants in blossom dominated all three stands. Participation of juvenile plants in populations was from $8 \%$ (Wicko Morskie) to 20\% (Jarosławiec), immature ones from 12\% (Wicko Morskie) to 24\% (Jarosławiec), and the ones at mature stage from $14 \%$ (Rowy) to $25 \%$ (Jarosławiec). A relatively low participation of juvenile specimens and immature in the population of Wicko Morskie is worth mentioning, which can cause substantial decrease of their number in a 3-4 years' time.

In the examined research stands, the diversity of the height of the plants was observed. The minimum height of E. atrorubens in Rowy was $7.0 \mathrm{~cm}, 8.9 \mathrm{~cm}$ in Wicko Morskie and $6.0 \mathrm{~cm}$ in Jarosławiec. The maximum length of the sprout found at the research stations of the Stowińskie Coast was $65.7 \mathrm{~cm}$ for the plants in Rowy, $49.3 \mathrm{~cm}$ for the plants in Wicko Morskie and $50.7 \mathrm{~cm}$ for the plants in Jarosławiec, respectively. The average height of the plants (Table 3) depending on the research station was: $31.9 \mathrm{~cm}$ (Rowy), $26.8 \mathrm{~cm}$ (Wicko Morskie) and $23.5 \mathrm{~cm}$ (Jarosławiec). According to Szlachetko (2001), the sprout of this species reaches the size of $20-80 \mathrm{~cm}$. According to Vakhrameevej (2008), such plants can grow from 25 to $60 \mathrm{~cm}$. From the data collected by Kull and Hutchings (2006) results, that in Estonia E. atrorubens grows up to the height of $57 \mathrm{~cm}$. There is no doubt that the height of the plants depends on the soil nutrients richness in the substratum (Ostrowska \& Porębska 2002). The coefficient of

Table 2. Age structure of the Epipactis atrorubens populations

\begin{tabular}{|c|c|c|c|c|c|c|c|c|c|c|}
\hline \multirow{3}{*}{ Locality } & \multicolumn{10}{|c|}{ Age spectra } \\
\hline & \multicolumn{2}{|c|}{ juvenile } & \multicolumn{2}{|c|}{ immature } & \multicolumn{2}{|c|}{ virginal } & \multicolumn{2}{|c|}{ generative } & \multicolumn{2}{|c|}{ Total } \\
\hline & number & $\%$ & number & $\%$ & number & $\%$ & number & $\%$ & number & $\%$ \\
\hline Rowy & 58 & 15 & 63 & 16 & 57 & 14 & 215 & 55 & 393 & 100 \\
\hline Wicko Morskie & 26 & 8 & 36 & 12 & 48 & 16 & 197 & 64 & 307 & 100 \\
\hline Jarosławiec & 73 & 20 & 87 & 24 & 89 & 25 & 112 & 31 & 361 & 100 \\
\hline
\end{tabular}



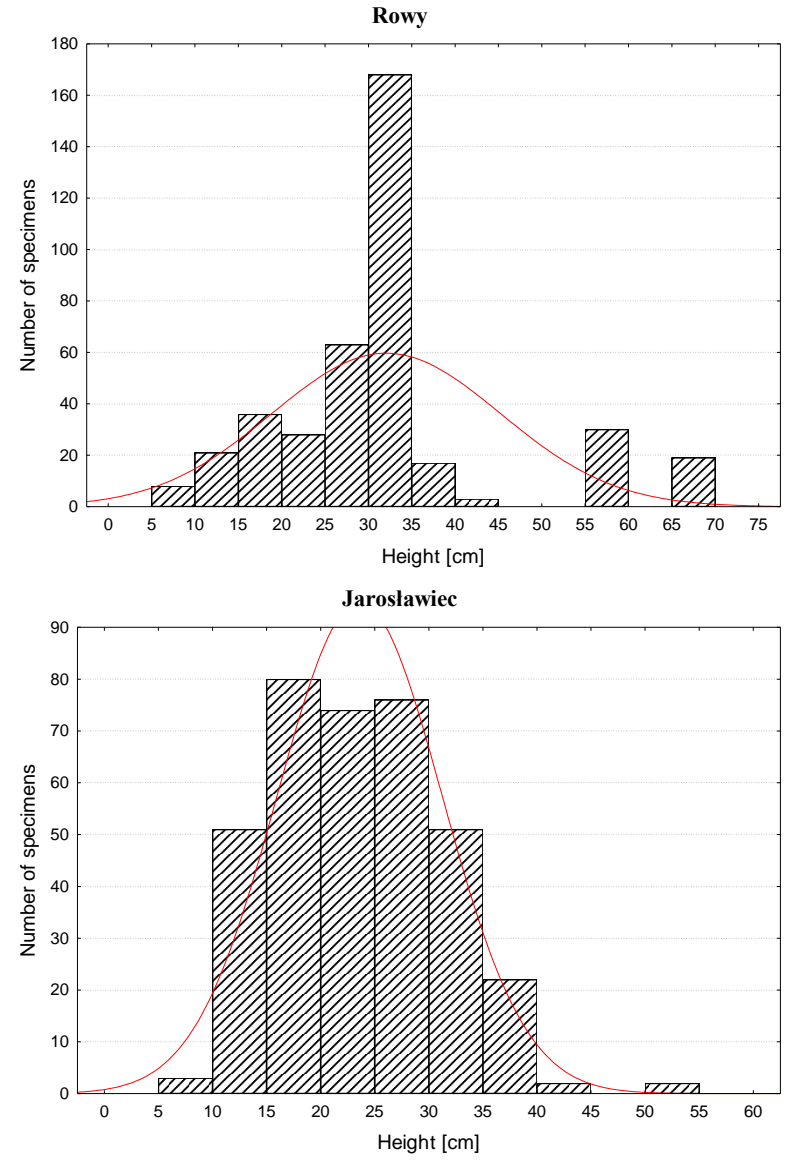

Figure 2. Histograms of heights of blooming plants in populations of Epipactis atrorubens

variation for this feature, depending on the research stand, is $21.4 \%$ to $41.2 \%$. The distribution of height is represented by bar charts (Fig. 2).

As far as E. atrorubens is concerned, there are about 8.9 leaves on the stem on average in plants originating in Rowy, 8.8 leaves in plants from Wicko Morskie and 6.9 leaves in plants from Jarosławiec (Table 3). The minimum number of leaves on the stem is from 3 to 5 . The maximum number of leaves in the case of measured individuals of $E$. atrorubens was 13 to 14. According to Szlachetko (2001) the plant usually produces from 4 to 9 leaves. However, according to Vakhrameeva et al. (2008) there can be from 7 to 9 , and maximum 12 . Undoubtedly, the number of the leaves on the stem depends on the height of each individual, however it can also be a characteristic of a species.

The average width of the largest leaf (Table 3) among population of E. atrorubens at the Słowińskie Coast is from 1.9 to $3.1 \mathrm{~cm}$. The minimum level of this parameter within the area of the stands is $0.5 \mathrm{~cm}$ for the individuals from Rowy, $1.6 \mathrm{~cm}$ for the plants from Wicko Morskie and $0.2 \mathrm{~cm}$ from individuals from Jarosławiec. The maximum width of the largest leaf is from 3.6 (Jarosławiec) to

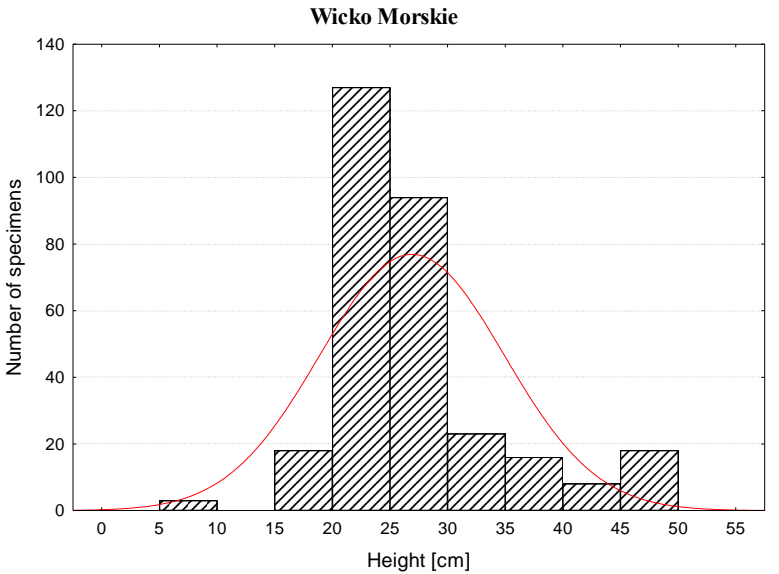

$5.1 \mathrm{~cm}$ (Rowy). According to Szlachetko (2001) the width of the leaves of this E. atrorubens varies from 1 to $4 \mathrm{~cm}$. The obtained results are close to the data which refer to Epipactics palustris presented by Antkowiak and Pankros (2000). According to the authors, the width of the largest leaf for individuals of this species was from 2.4 to $6.4 \mathrm{~cm}$. According to Golis and Bednorz (2001), the value of this parameter was from 1.1 to $4.5 \mathrm{~cm}$. Therefore, we can conclude that the width of the largest leaf can be a characteristic feature shared within one genus.

The number of flowers in inflorescence also varies substantially within the research stands. On average, the number is from 17.1 to 24.1 flowers. Within the area of research stands, the minimum value of that parameter is 6 pieces for the plants from Rowy, 2 for the specimens from Wicko Morskie and 1 for the plants from Jarosławiec. The maximum observed number of flowers in the inflorescence is from 41 to 46 . In comparison to Epipactics palustris, E. atrorubens produces substantially more flowers. According to it, the data collected by Antkowiak and Pankros (2000), in the case of E. palustris the number of flowers in inflorescence was from 7 to 26 pieces. While, according to 
Table 3. Individual features of blooming plants of Epipactis atrorubens

\begin{tabular}{|c|c|c|c|c|}
\hline Characteristic & Min. & Max. & Mean \pm standard deviation & $\begin{array}{c}\text { Variation coefficient } \\
(\%)\end{array}$ \\
\hline \multicolumn{5}{|c|}{ Rowy $(\mathrm{n}=215)$} \\
\hline Height of plant $(\mathrm{cm})$ & 7.0 & 65.7 & $31.9 \pm 13.1$ & 41.2 \\
\hline Number of leaves (pcs.) & 4.0 & 14.0 & $8.9 \pm 2.3$ & 25.8 \\
\hline Width of the greatest leaf $(\mathrm{cm})$ & 0.5 & 5.1 & $3.1 \pm 1,1$ & 35.6 \\
\hline Number of flowers (pcs.) & 6.0 & 46.0 & $24.1 \pm 9.2$ & 37.9 \\
\hline Lenght of inflorescence $(\mathrm{cm})$ & 2.3 & 28.7 & $9.9 \pm 6.4$ & 64.7 \\
\hline Lenght of bracts $(\mathrm{cm})$ & 0.3 & 6.7 & $3.4 \pm 1.3$ & 39.0 \\
\hline Width of bracts $(\mathrm{cm})$ & 0.2 & 3.0 & $0.5 \pm 0.2$ & 50.2 \\
\hline \multicolumn{5}{|c|}{ Wicko Morskie $(\mathrm{n}=197)$} \\
\hline Height of plant $(\mathrm{cm})$ & 8.9 & 49.3 & $26.8 \pm 7.9$ & 29.7 \\
\hline Number of leaves (pcs.) & 5.0 & 13.0 & $8.8 \pm 1.7$ & 19.0 \\
\hline Width of the greatest leaf $(\mathrm{cm})$ & 1.6 & 4.6 & $2.5 \pm 0.5$ & 19.6 \\
\hline Number of flowers (pcs.) & 2.0 & 41.0 & $20.2 \pm 8.3$ & 41.1 \\
\hline Lenght of inflorescence $(\mathrm{cm})$ & 2.6 & $27 ., 3$ & $11.9 \pm 5.9$ & 49.9 \\
\hline Lenght of bracts $(\mathrm{cm})$ & 1.6 & 6.7 & $3.7 \pm 1.1$ & 29.8 \\
\hline Width of bracts $(\mathrm{cm})$ & 0.1 & 1.4 & $0.5 \pm 0.2$ & 32.8 \\
\hline \multicolumn{5}{|c|}{ Jarosławiec $(\mathrm{n}=112)$} \\
\hline Height of plant $(\mathrm{cm})$ & 6.0 & 50.7 & $23.5 \pm 5.0$ & 21.4 \\
\hline Number of leaves (pcs.) & 3.0 & 13.0 & $6.9 \pm 1.5$ & 21.6 \\
\hline Width of the greatest leaf $(\mathrm{cm})$ & 0.2 & 3.6 & $1.9 \pm 0.6$ & 28.7 \\
\hline Number of flowers (pcs.) & 1.0 & 42.0 & $17.1 \pm 7.2$ & 42.4 \\
\hline Lenght of inflorescence $(\mathrm{cm})$ & 0.5 & 32.2 & $12.4 \pm 5.3$ & 42.5 \\
\hline Lenght of bracts $(\mathrm{cm})$ & 0.5 & 6.5 & $2.9 \pm 1.2$ & 39.2 \\
\hline Width of bracts $(\mathrm{cm})$ & 0.2 & 1.8 & $0.5 \pm 0.3$ & 60.8 \\
\hline
\end{tabular}

$\mathrm{n}$ - size of the population

Kolon et al. (1995) the number of flowers in this species is from 6 to 16 pieces. Undoubtedly, the number of flowers in inflorescence depends on the length of inflorescence, which in turn is a constituent of the height of the plant. Therefore, the height of the plant should have a vital impact on number of its flowers. That relationship is represented in Table 4. According to the table, in all measured specimens of Epipactis atrorubens, the number of flowers in inflorescence depends on its length, and at the same time on the height of the plant. The analyzed features show strong correlation with one another. The height the plant of $E$. atrorubens, the length of the inflorescence increases which results in the number of produced flowers. It can be evidenced by substantially vital statistical values of Pearson's correlation coefficient $(\mathrm{r}=0.64$, for Rowy, $\mathrm{r}=0.77$ for Wicko Morskie and $\mathrm{r}=0.73$ for the stand in Jarosławiec, respectively) (Table 4). The variability of the analyzed parameter is from $37.5 \%$ for the population from Rowy to $42.4 \%$ for the population from Jarosławiec (Table 3).

The length of inflorescence up to bracts (Table 3) among populations of E. atrorubens at the Słowińskie Coast is from $9.9 \mathrm{~cm}$ for the plants from the stand in Rowy to $12.4 \mathrm{~cm}$ for the plants from Jarosławiec. This characteristic feature shows high diversity within all populations under consideration. Within the area of particular stands, the minimum value of the parameter is $2.3 \mathrm{~cm}$ for Rowy, 
Table 4. Matrix correlations Pearson's coefficient for $\mathrm{p}<0.05$ between individual features research of Epipactis atrorubens

\begin{tabular}{|c|c|c|c|c|c|c|c|c|}
\hline \multirow{2}{*}{ Locality } & \multirow{2}{*}{$\begin{array}{l}\text { Individual } \\
\text { features }\end{array}$} & \multicolumn{7}{|c|}{ Individual features } \\
\hline & & 1 & 2 & 3 & 4 & 5 & 6 & 7 \\
\hline \multirow{7}{*}{ 文旾 } & 1 & 1.00 & & & & & & \\
\hline & 2 & 0.52 & 1.00 & & & & & \\
\hline & 3 & 0.84 & 0.48 & 1.00 & & & & \\
\hline & 4 & 0.80 & 0.42 & 0.60 & 1,00 & & & \\
\hline & 5 & 0.64 & 0.11 & 0.31 & 0.74 & 1.00 & & \\
\hline & 6 & 0.43 & 0.04 & 0.44 & 0.59 & 0.61 & 1.00 & \\
\hline & 7 & $\mathbf{0 . 3 3}$ & -0.13 & 0.24 & 0.51 & 0.51 & 0.65 & 1.00 \\
\hline \multirow{7}{*}{ 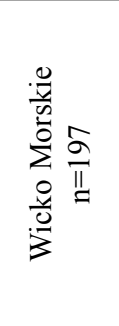 } & 1 & 1.00 & & & & & & \\
\hline & 2 & 0.25 & 1.00 & & & & & \\
\hline & 3 & 0.43 & 0.37 & 1.00 & & & & \\
\hline & 4 & 0.82 & 0.43 & 0.40 & 1.00 & & & \\
\hline & 5 & 0.77 & -0.01 & 0.21 & 0.70 & 1,00 & & \\
\hline & 6 & -0.15 & -0.05 & 0.15 & -0.09 & 0.05 & 1.00 & \\
\hline & 7 & -0.11 & -0.18 & 0.13 & -0.10 & 0.04 & 0.80 & 1.00 \\
\hline \multirow{7}{*}{ 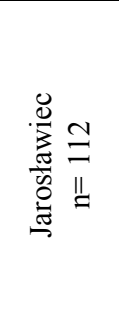 } & 1 & 1.00 & & & & & & \\
\hline & 2 & 0.23 & 1.00 & & & & & \\
\hline & 3 & 0.52 & 0.17 & 1.00 & & & & \\
\hline & 4 & 0.66 & 0.18 & 0.53 & 1.00 & & & \\
\hline & 5 & 0.73 & -0.13 & 0.36 & 0.67 & 1.00 & & \\
\hline & 6 & 0.43 & -0.23 & 0.41 & 0.31 & 0.45 & 1.00 & \\
\hline & 7 & 0.19 & -0.33 & 0.34 & 0.21 & 0.38 & 0.70 & 1.00 \\
\hline
\end{tabular}

$\mathrm{n}$ - size of population, 1 - Height of plant (cm), 2 - Number of leaves (pcs.), 3 - Width of the greatest leaf (cm), 4 - Number of flowers (pcs.), 5 - Lenght of inflorescence $(\mathrm{cm}), 6$ - Length of bracts $(\mathrm{cm}), 7$ - Width of bracts $(\mathrm{cm})$

$2.6 \mathrm{~cm}$ for Wicko Morskie and $0.5 \mathrm{~cm}$ for Jarosławiec. The maximum observed length of inflorescence to the bract is from $27.3 \mathrm{~cm}$ for the individuals from Wicko Morskie to $32.2 \mathrm{~cm}$ for the population from Jarosławiec. The coefficient of variation of the length of the inflorescence to the bract is from $42.5 \%$ to $64.7 \%$.

The average length of the bract within the area of the populations under consideration is $3.4 \mathrm{~cm}$ for the plants from Rowy, $3.7 \mathrm{~cm}$ for the plants form Wicko Morskie and $2.9 \mathrm{~cm}$ for the specimens from Jarosławiec. The minimum value of that parameter is $0.3 \mathrm{~cm}$ (Rowy) to $1.6 \mathrm{~cm}$ (Wicko Morskie). The maximum length of the bract was from 6.5 to $6.7 \mathrm{~cm}$. Comparing the data collected at the Słowińskie Coast related to E. palustris with the data obtained by Kolon et al. (1995) and Antkowiak and Pankros (2000), we can say, that the plants represent similarity as to the analyzed feature. The length of the bract in $E$. palustris was from 1.2 to $5.0 \mathrm{~cm}$ for the population from the banks of Lake Pomorze in the Augustów Primaeval Forest and from 2.0 do $12.5 \mathrm{~cm}$ for the population from the Wielkopolska National Park. Therefore, the analyzed feature may be characteristic of the genus, however conditioned by the parameters of the habitat. The coefficient of variation of that feature was from $29.8 \%$ for Wicko Morskie to $39.2 \%$ for Jarosławiec.

In all these populations, the length of inflorescence up to the bract, the width and the length of the bract were recognized as the most variable features. The least variable was the number of leaves in the stem. The variation of the other features varied depending on the research stand. The distribution of all the analyzed features in blooming individuals was normal or close to normal.

For the individual features the Paerson correlation coefficients were determined and the $t$ tests of diversity of the said features were performed. The results are presented in the tables 4 and 5 . In all populations, statistically significant differences between the height of the plant and the width of the largest leaf, the number of flowers in inflorescence and the length of the inflorescence to the bract were found as well as between the number of flowers in inflorescence and the length of the inflorescence up to the bract. The vital relation was also found between the length the width of the bract. Correlation coefficients for such features were: $r=0.65$ (Rowy), $r=0.80$ (Wicko Morskie) and $r=0.70$ (Jarosławiec) respeclively. In the case of the population originating in Rowy and Jarosławiec, statistical 
Table 5. The results analysis of variance (Anova test) of significance of individual characteristic features of E. atrorubens at research stands

\begin{tabular}{|l|c|c|c|c|c|}
\hline \multicolumn{1}{|c|}{ Variable } & SS & DF & MS & $F_{\text {value }}$ & $\mathrm{p}$ \\
\hline Height of plant (cm) & 13500 & 2 & 6774.0 & 66.52 & $<0.001$ \\
\hline Number of leaves (pcs.) & 980.7 & 2 & 490.4 & 137.5 & $<0.001$ \\
\hline Width of the greatest leaf (cm) & 242.0 & 2 & 121.0 & 190.0 & $<0.001$ \\
\hline Number of flowers (pcs.) & 933.1 & 2 & 4665.0 & 67.67 & $<0.001$ \\
\hline Lenght of inflorescence (cm) & 1291.0 & 2 & 645.5 & 18.48 & $<0.0001$ \\
\hline Lenght of bracts (cm) & 97.90 & 2 & 48.95 & 32.98 & $<0.0001$ \\
\hline Width of bracts (cm) & 0.175 & 2 & 0.087 & 1.503 & $>0.05$ \\
\hline
\end{tabular}

SS-sum of squares, DF-degrees of freedom, MS-mean square, $\mathrm{F}_{\text {value }}$-mean of the within group variances, $\mathrm{p}$-significance level

significant correlations were established between the width of the largest leaf and number of flowers in inflorescence $(\mathrm{r}=0.60$ and $\mathrm{r}=0.53)$ respectively and average relation in the case comparable features for the research standing in Wicko Morskie $(\mathrm{r}=0.40)$.

For the population of E. atrorubens from Rowy, a very strong relation was found between the height of the plants and the number of leaves in the stem and between the number of flowers in inflorescence and the length and height of the bract. For the population from Jarosławiec, the average correclation between the number of flowers in inflorescence and the width of the bract was evidenced $(\mathrm{r}=0.31$, at $\mathrm{p}<0.05)$. The length of the inflorescence up to the bract is also connected with the length and the width of the bract (respectively: $r=0.61$ and 0.51 at $p<0.05$ for the population in Rowy and $r=0.45$ and $0.38, p<0.05$ for the population in Jarosławiec). In the case of the population from Jarosławiec, it was found that the width of the bract decreases along with the increase in the number of leaves $(\mathrm{r}=-0.33$ at $\mathrm{p}<0.05)$.

In populations from Rowy and Wicko Morskie, there are average correlation between the number of leaves in the stem and the width of the largest leaf $(r=0.48$ at $\mathrm{p}<0.05$ for Rowy and $\mathrm{r}=0.37$ at $\mathrm{p}<0.05$ for Wicko Morskie) and the number of leaves in the stem and the number of flowers in inflorescence $(r=0.42$ at $\mathrm{p}<0.05$ for Rowy and $\mathrm{r}=0.43$ at $\mathrm{p}<0.05$ for Wicko Morskie). The E. atrorubens individuals originating in Rowy and Jarosławiec also show average positive correlation between the width of the largest leaf and the length of the inflorescence to the bract and the length and width of the bract (Table 4).

Analysis of variance (Anova test) showed vital statistical diversity of the populations under consideration as to the height of the plants $(p<0.001)$, the number of leaves $(p<0.001)$, the width of the largest leaf $(p<0.001)$, the number of flowers $(p<0.001)$, lenght of inflorescence $(p<0.0001)$ and lenght of bract $(p<0.0001)$ (Table 5). It was also established that the width of the bract ( $p>0.05)$, as the only characteristic feature does not reveal any vital statistical differences between all specimens of E. atrorubens under consideration independent of the research stand.

\subsection{Edaphic conditions}

At the research stands in Rowy, Wicko Morskie and Jarosławiec the fraction of medium sand dominated (0.5$0.25 \mathrm{~mm}$ ) (Fig. 3). The dust sand fractions represented the lowest percentage in the composition of the soil at all research stands. The share of the remaining fractions varied within the area of each stand. The sand fraction indicated that the examined soil is loose and slack. There are big spaces between the sand grains which leads to fast percolation of water. The water capacity of such soils is very small but they are characterized by good permeability (Bednarek et al. 2004).

The second, as to proportion, soil composition fraction at research stations was the fraction of fine sand (0.25-0.10 $\mathrm{mm})$. It constituted $17.4 \%$ of all grains in Rowy, $16.6 \%$ in Wicko Morskie and 30.7\% in Jarosławiec, respectively. As to the grain size composition, the soil from the research stand in Jarosławiec was the most outstanding. The core part of the soil consisted of gravel, whose content was $11.1 \%$. Among the earthy parts, beside domination of medium sand $(45.4 \%)$, there was visible content of fine sand $(30.7 \%)$. The coarse sand $(1.0-0.5 \mathrm{~mm})$ constituted $11.9 \%$. In the soil of the research stand in Jarosławiec the established content of powdery fractions was much higher than in other research stands.

The soils with predominantly silty particles are considered to be of better quality. According to Bednarek et al. (2004), between the particles of powder sand there are capilar spaces in which the water can be retained.

The laboratory tests revealed that the populations of E. atrorubens examined at the Słowińskie Coast as to the 


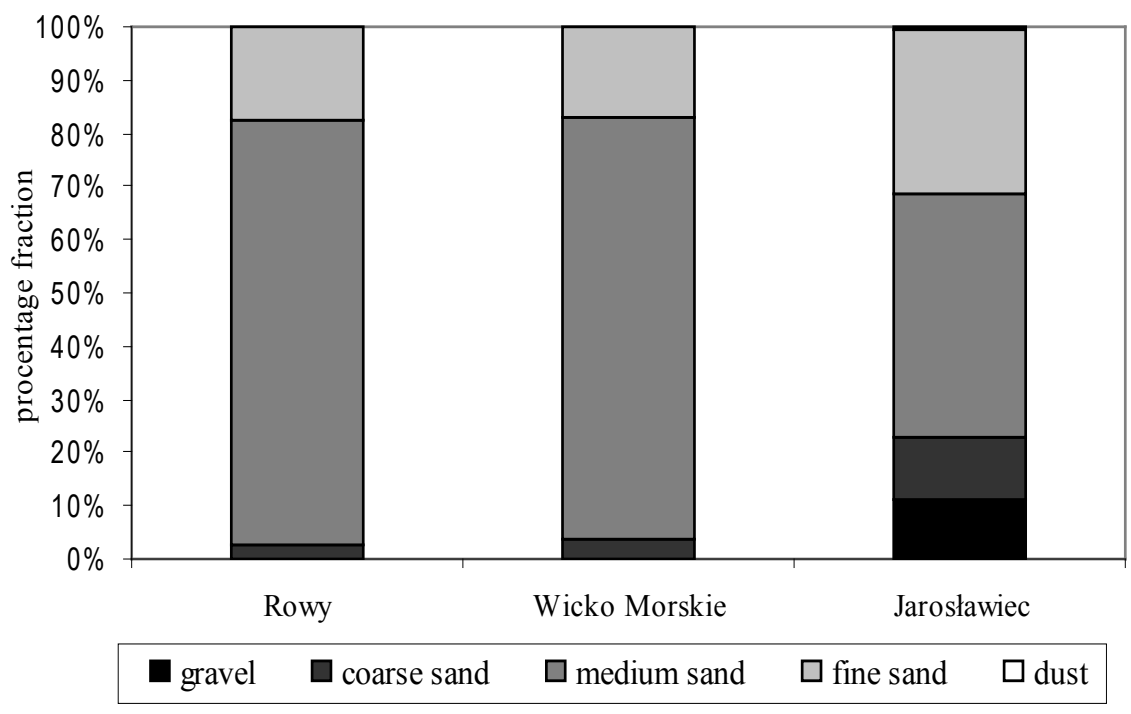

Figure 3. Granulation composition of soils

$\mathrm{pH}_{\mathrm{H} 2 \mathrm{O}}$ and $\mathrm{pH}_{\mathrm{KCl}}$ reaction cover the soils of low acidity or close to neutral and even slightly alkaline reaction (Table 6). The obtained results confirm the data provided by Szlachetko (2001) according to which E. atrorubens grows in the soils of the acidity close to neutral and even slightly alkaline. According to Jurkiewicz et al. (2001) E. atrorubens in Southern Poland covers the soils of neutral acidity or slightly alkaline. According to the research done by Kull and Hutchings (2006) and Vakhrameeva et al. (2008) that genus can be found in the soils with $\mathrm{pH}$ from 7.5 to 9.0. According to the research by Tsiftsis et al. (2008) done in Eastern Macedonia, this genus covers the soils of $\mathrm{pH}$ from 6.5 to 7.7. The results obtained at the Słowińskie Coast, are closer in their scope to the results obtained in Eastern Macedonia.

The organic matter content in the soil from micro habitats Epipactis atrorubens did not exceed 1\% (Table 6) showing small diversity as to the analyzed index. Jurkiewicz et al. (2001) in his research discovered higher concen- tration of organic matter in the soil where E. atrorubens grew (from 1.1 to 5.0\%), and Tsiftsis et al. (2008) from 7.9 to $30.2 \%$. The small content of organic matter in the research stands of the Słowińskie Coast results from habitat conditions in which they grew.

The average content of exchangeable aluminum $\mathrm{Al}^{3+}$ in tested soil samples was from 0.012 to $0.024 \mathrm{cmol}_{(+)} \cdot \mathrm{kg}^{-1}$ of soil (Table 6). It undoubtedly is connected with low acidity of environment and even close to neutral of the habitat where the E. atrorubens grew. According to Ostrowska et al. (1991), the content of mobile aluminum in soil especially depends on its acidity (Gworek 2006). When acidity of the environment increases, the volume of free ions of aluminum grows higher.

The samples of the tested mineral soil showed low salinity from $0.14 \mathrm{~g} \cdot \mathrm{dm}^{-3} \mathrm{NaCl}$ in Jarosławiec to $0.19 \mathrm{~g} \cdot \mathrm{dm}^{-3}$ $\mathrm{NaCl}$ at the research stand in Wicko Morskie (Table 6). The obtained salinity values have no negative impact on plants development.

Table 6. Selected properties of researched soils

\begin{tabular}{|c|c|c|c|c|c|c|}
\hline \multicolumn{2}{|c|}{ Locality } & $\begin{array}{l}\mathrm{pH} \\
\mathrm{H}_{2} \mathrm{O}\end{array}$ & $\begin{array}{l}\mathrm{pH}, \\
\mathrm{KCl}\end{array}$ & $\begin{array}{c}\text { Organic } \\
\text { matter [\%] }\end{array}$ & $\begin{array}{c}\mathrm{Al}^{3+} \\
\mathrm{cmol}_{(+)} \cdot \mathrm{kg}^{-1}\end{array}$ & $\begin{array}{c}\text { Salinity } \\
\mathrm{g} \cdot \mathrm{dm}^{-3} \mathrm{NaCl}\end{array}$ \\
\hline Rowy & \multirow{3}{*}{$\begin{array}{c}\text { Average } \pm \text { SD } \\
\text { Min - Max }\end{array}$} & $\begin{array}{l}6.6 \pm 0.4 \\
6.3-7.0\end{array}$ & $\begin{array}{l}6.7 \pm 0.2 \\
6.4-6.9\end{array}$ & $\begin{array}{c}0.7 \pm 0.12 \\
0.5-0.8\end{array}$ & $\begin{array}{c}0.020 \pm 0.002 \\
0.016-0.019\end{array}$ & $\begin{array}{c}0.17 \pm 0.02 \\
0.15-0.18\end{array}$ \\
\hline Wicko Morskie & & $\begin{array}{l}5.9 \pm 0.3 \\
5.6-6.2\end{array}$ & $\begin{array}{l}6.1 \pm 0.4 \\
5.6-6.4\end{array}$ & $\begin{array}{c}0.8 \pm 0.33 \\
0.5-1.0\end{array}$ & $\begin{array}{c}0.012 \pm 0.001 \\
0.012-0.013\end{array}$ & $\begin{array}{l}0.18 \pm 0.24 \\
0.15-0.19\end{array}$ \\
\hline Jarosławiec & & $\begin{array}{l}6.4 \pm 0.4 \\
6.2-6.9\end{array}$ & $\begin{array}{c}6.1 \pm 0.04 \\
6.0-6.1\end{array}$ & $\begin{array}{c}0.4 \pm 0.08 \\
0.3-0.5\end{array}$ & $\begin{array}{c}0.024 \pm 0.005 \\
0.018-0.028\end{array}$ & $\begin{array}{c}0.15 \pm 0.004 \\
0.14-0.15\end{array}$ \\
\hline
\end{tabular}

SD- standard deviation 


\section{Conclusions}

The tested populations of E. atrorubens included from 307 to 393 specimen at different stages of development, however, the blooming ones dominated. The normal character of distribution of individual features of blooming plants proves their undisturbed development. In tested populations, statistically significant correlations were found between the height of the plant and the width of the largest leaf, the number of flowers in inflorescence and the length of inflorescence to the bract, as well as between the statistically significant correlations number of flowers in inflorescence and the length of inflorescence up to the bract. The vital relationship was also found between the length and the width of the bract. Analysis of variance (Anova test) showed vital statistical diversity of the populations under consideration as to the height of the plants, the number of leaves, the width of the largest leaf, the number of flowers, lenght of inflorescence and lenght of bract. It was also established that the width of the bract, as the only characteristic feature does not reveal any significant statistical differences between all specimens of $E$. atrorubens under consideration independent of the research stand.

Populations of E. atrorubens at the Słowińskie Coast cover the mineral soil with more fractions of medium and fine sand. Those soils are loose and slack of very low water capacity and characteristic of good permeability. The organic matter content varied from 0.4 to $0.8 \%$. The soil had low acidity or close to alkaline. The tested samples of soil were characteristic of very low content of exchangeable $\mathrm{Al}^{3+}$ ions, which results from relatively high $\mathrm{pH}$ levels. Salinity of that soil was low and the average content of $\mathrm{NaCl}$ was between 0.146 and $0.181 \mathrm{~g} \cdot \mathrm{dm}^{-3}$.

\section{Acknowledgments}

The research was feasible thanks to permissions of Provincial Nature Conservation Officers in Gdańsk and Szczecin of RDOŚ-22-PN.II-6631-1-34/09/ml and RDOS-32-WO$\mathrm{PN}-6631 / \mathrm{r} / 0 / 47 / 09 / 10 / \mathrm{mk}$.

\section{References}

Antkowiak W. \& Pankros J., 2000, Charakterystyka ekologiczna populacji kruszczyka błotnego (Epipactis palustris (L.) Crantz) z Wielkopolskiego Parku Narodowego [Occurrence and ecological conditions of Epipactis palustris (L.) Crantz) from Wielkopolski National Park], Roczniki Akademii Rolniczej w Poznaniu - CCCXXII, Bot. 3: 3-11.

Bednarek R., Dziadowiec H., Pokojska U. \& Prusinkiewicz Z., 2004, Badania ekologiczno-gleboznawcze
[Research of soil and ecological], Wyd. Nauk. PWN, Warszawa.

Braun-Blanquet J., 1964, Pflanzensoziologie: Grundzüge der Vegetationkunde, Springer-Verlag, Wien, New York.

Braun M., 2010, Nadmorskie wydmy szare Helichryso-Jasionetum litoralis [Coastal dunes grey Helichryso-Jasionetum litoralis], [in]: W. Mróz (ed.), Monitoring siedlisk przyrodniczych. Przewodnik metodyczny, część I [Monitoring of habitats. Methodical Guide, Part I], Biblioteka Monitoringu Środowiska, Warszawa: 61-72.

Brzosko E., Tałataj I. \& Wróblewska A., 2006, Genetic structure of rare Epipactis atrorubens populations from two National Parks of northeast Poland, Polish Botanical Studies 22: 1-10.

Golis A. \& Bednorz L., 2001, Charakterystyka populacji kruszczyka błotnego Epipactis palustris (Will.) $\mathrm{Cr}$. w Rezerwacie Przyrody „Mielno” koło Konina [Occurrence and ecological conditions of Epipactis palustris (Will.) Cr. in the nature reserve "Mielno" near Konin], Roczniki Akademii Rolniczej w Poznaniu CCCXXXIV, Bot. 4: 71-81.

Gworek B., 2006, Glin w środowisku przyrodniczym a jego toksyczność [Aluminium in the natural environment and his toxicity], Ochrona Środowiska i Zasobów Naturalnych 29: 27-38.

Jakubska-Busse A., 2009, Storczyki - piękno i tajemnica natury [Orchises - the beauty and the mysteries of nature], Polski Klub Ekologiczny, Dwumiesięcznik Okręgu Dolnośląskiego Zielona Planeta 1 (82)/2009: 19-21.

Jurkiewicz A., Turnau K., Mesjasz - Przybyłowicz J., Przybyłowicz W. \& Godzik B., 2001, Heavy metal localisation in mycorrhizas of Epipactis atrorubens (Hoffm.) Besser (Orchidaceae) from zinc mine tailings, Protoplasma 218: 117-124.

Karczewska A. \& Kabała C., 2008, Metodyka analiz laboratoryjnych gleb i roślin, wyd. 4 [Methodology of laboratory analyses of the soil and plants, $4^{\text {th }}$ edition], Uniwersytet Przyrodniczy we Wrocławiu, Wrocław.

Kolon K., Krawczyk J. \& Krawczyk A., 1995, Charakterystyka ekologiczna populacji Epipactis palustris (L.) Crantz znad jeziora Pomorze w Puszczy Augustowskiej [Occurrence and ecological conditions of Epipactis palustris (L.) Crantz) from Pomorze Lake in Augustowska Forest], Acta Universitatis Wratislaviensis No 1717, Prace Bot. LXIII, Wyd. Uniwersytetu Wrocławskiego, Wrocław.

Kull T. \& Hutchings M. J., 2006, A comparative analysis of decline in the distribution ranges of orchid species in Estonia and the United Kingdom, Biological Conservation 129: 31-39.

Łukasiewicz A., 1962, Morfologiczno-rozwojowe typy bylin [Morphologic development types of perennials], Prace Kom. Biol. PTPN, 27(1): 3-397. 
Ochyra R., Żarnowiec J. \& Bednarek-Ochyra H., 2003, Census catalogue of Polish mosses [Katalog mchów Polski], Polish Academy of Sciences, Institute of Botany, Kraków.

Ostrowska A., Gawliński S. \& Szczubiałka Z., 1991, Metody analizy i oceny właściwości gleb i roślin [Methods of analysis and evaluation of soil properties and plants], Katalog, Instytut Ochrony Środowiska, Warszawa.

Ostrowska A. \& Porębska G., 2002, Skład chemiczny roślin, jego interpretacja i wykorzystanie w ochronie środowiska [The chemical composition of plants, his interpretation and the application in the environmental protection], Monografia, Inst. Ochr. Środ.,Warszawa.

Matuszkiewicz W., 2008, Przewodnik do oznaczania zbiorowisk roślinnych Polski [Guide to identification of plant communities of Poland], Wyd. PWN, Warszawa.

Mirek Z., Piękoś-Mirkowska H., Zając A. \& Zając M., 2002, Flowering plants and pteridophytes of Poland a checklist [Krytyczna lista roślin naczyniowych Polski], W. Szafer Institute of Botany, Polish Academy of Sciences, Kraków.

Sarosiek J., Krukowski-Zdanowicz J. \& Woroniecka G., 1990, The ecological organization of Epipactis palustris (Mill.) Cr. population in Augustów Forest, [in:] J.
Sarosiek (ed.) Proceedings of the Symposium on Biology and Ecology of European Orchids, Held at Wrocław University, Karpacz, May 30-June 3, 1985.

Szlachetko D. L., 2001, Storczyki [Orchids], Multico Oficyna Wydawnicza, Warszawa.

Szweykowska A. \& Szweykowski J., 2006, Botanika. Systematyka [Botany. Systematics], PWN, Warszawa.

Tałataj I. \& Brzosko E., 2008, Selfing potential in Epipactis palustris, E. helleborine and E. atrorubens (Orchidaceae), Plant Systematics and Evolution 276: 21-29.

Tsiftsis S., Tsiripidis I., Karagiannakidou V. \& Alifragis D., 2008, Niche analysis and conservation of the orchids of east Macedonia (NE Greece), Acta Oecologica 33: 27-35.

Tuulik T., 1998, Hiiumaa orhideed. Biosfääri Kaitseala Himiumaa Keskus, Pirrujaak 5: 1- 134.

Vakhrameeva M. G., Tatarenko I. V., Varlygina T. I., Torosyan G. K. \& Zagulskii M. N., 2008, Orchids of Russia and adjacent countries (within the borders of the former USSR), A. R.G. Gantner Verlang K. G., Ruggell/ Liechtenstein.

Wołek J., 2006, Wprowadzenie do statystyki dla biologów [Leading into statistics for biologists], Akad. Przyr., Kraków. 